different oral contraceptives are to be compared with a control group is in progress and the results will be reported in a later communication.

W'e are grateful to the staff and patients of the Carshalton Family Planning Association Clinic for their co-operation, and to Mrs.
J. Ellson and Mrs. M. Russell, who interviewed the patients. Dr. C. C. Spicer, Mrs. Maryse Metcalfe, Dr. Derek Richter, Dr. David M. Shaw, Dr. Martin Vessey, and Mr. Richard Peto gave valuable advice and help with the preparation of the manuscript.

Address reprint requests to Dr. Brenda Herzberg.

\title{
REFERENCES
}

Beck, A. T., Ward, C. H., Mendelson, M., Mock, J., and Erbaugh, J. (1961) Archives of General Psychiatry, 4, 561 .

Binks, R., Cambourn, P., and Papworth, R. A. (1962). Medical Journal of Australia, 49(i), 716.

British Medical fourmal, 1967, 3, 627.

Goldzieher, J. W., Moses, L. E., and Ellis, L. T. (1962). fournal of the American Medical Association, 180, 359.

Grant, E. C. G. (1967). Fournal of Obstetrics and Gynaecology of the British Commonwealth, 74, 908.

Grant, E. C. G. (1969). British Medical fournal, 4, 73.

Hauser, G. A., and Schubiger, V. (1965). Archiv für Gynäkologie, 202, 175. Herzberg, B., and Coppen, A. (1970). British fournal of Psychiatry, 116, 161 .
Kane, F. J., Daly, R. J., Ewing, J., and Keeler, M. (1967). British fournal of Psychiatry, 113, 265.

Kaye, B. M. (1963). Fournal of the American Medical Association, 186, 522. Lewis, A., and Hoghughi, M. (1969). British Yournal of Psychiatry, 115, 697. Mears, E., and Grant, E. C. G. (1962). British Medical Fournal, 2, 75.

Metcalfe, M., and Goldman, E. (1965). British fournal of Psychiatry, 111, 240.

Moos, R.H. (1968). Archives of General Psychiatry, 19, 87.

Nilsson, A, Jacobson, L., and Ingemanson, C.-A. (1967). Acta Obstetrica et Gynaecologica Scandinavica, 46, 537.

Pichot, P., Piret, J., and Clyde, D. J. (1966). Revue de Psychologie Appliquée,

Pullen, D. (1962). British Medical fournal, 2, 1016.

\section{Controlled Clinical Trial of Combined Triodothyronine and Thyroxine in the Treatment of Hypothyroidism}

\author{
R. N. SMITH, ${ }^{*}$ M.D., B.SC., M.R.C.P.ED. ; S. A. TAYLOR† ; J. C. MASSEY, $\ddagger$ B.SC.
}

\author{
British Medical fournal, 1970, 4, 145-148
}

\begin{abstract}
S ummary: A double-blind cross-over trial of a combined D preparation of triiodothyronine and thyroxine (1:4 ratio) compared with thyroxine alone was conducted with 99 patients previously stabilized on .thyroxine as treatment for hypothyroidism. Four patients were excluded during the trial and eight afterwards owing to gross deficiencies in taking the tablets. Of the remaining 87 patients $42(48 \%)$ had no preference for either medication, 29 (33\%) preferred thyroxine alone, and $16(18 \%)$ the combination. A high incidence of unpleasant symptoms was experienced during the two months' treatment with the combined preparation. The serum protein-bound iodine levels were lowered (mean reduction $1.8 \mu \mathrm{g} . / 100$ ml.) on the combination, but the labelled $T_{3}$-resin sponge uptake values were not altered and remained in the normal range on both treatments.
\end{abstract}

\section{Introduction}

Thyroxine ( $\mathrm{L}$-thyroxine) and triiodothyronine (3,5,3'-tri-iodo- $\mathrm{L}$ thyronine) are the circulating thyroid hormones in man. Both hormones have been synthesized and each is effective alone in the treatment of hypothyroidism. In contrast to dried thyroid extracts (thyroid B.P., desiccated thyroid U.S.P., thyroglobulin U.S.P.) the composition and potency of triiodothyronine and thyroxine are constant but they differ from each other in physiological action. The dissimilarities of the two hormones are partly due to differences in their binding to protein in both blood and tissues. Thyroxine has a lnnger biological half-life than triiodothyronine and their effects on laboratory tests of thyroid status differ. The serum protein-bound iodine of patients treated with thyroxine is disproportionately high when compared with their metabolic status and low when triiodothyronine alone is used.

Combinations of synthetic triiodothyronine and thyroxine

\footnotetext{
- Lecturer.

$t$ Technician.

Department of Pharmacology and Therapeutics, University of Sheffield, Royal Infirmary, Sheffield S6 3DA

\# Biochemist, Department of Chemical Pathology, United Sheffield

Hospitals, Children's Hospital, Sheffield S10 2TH.
}

have been introduced in Britain (Taylor, 1961; Taylor et al., 1970) and the United States (Wool and Selenkow, 1965; Selenkow and Wool, 1967), and compared with dried thyroid extracts such preparations have the advantage of constant potency. Furthermore, it has been claimed that a 1:4 combination of triiodothyronine and thyroxine mimics the metabolic action of dried thyroid extracts and also produces biochemical values commensurate with the patient's metabolic status (Selenkow and Wool, 1967). These studies were limited to previously untreated hypothyroid patients and were not adequately controlled. There has been no published report of a valid comparison of combined triiodothyronine and thyroxine with either dried thyroid extract or thyroxine alone, and therefore the present study was undertaken.

\section{Patients and Methods}

Selection of Patients.-Patients treated for hypothyroidism with either 200 or $300 \mu \mathrm{g}$. of L-thyroxine sodium daily for at least six months or longer and judged to be euthyroid were interviewed. The nature and purposes of the clinical trial were explained before asking for the patients' co-operation; those for whom the additional visits would result in financial loss were excluded. The patient's family doctor was notified of the alt -ation in treatment and general design of the trial.

Randok iion.-Patients comprised three groups based on the cause of the hypothyroidism: spontaneous, following thyroid surgery, or after radioiodine therapy. The sequence of treatment within each group had been randomized and coded by an independent pharmacist so that each patient received thyroxine ( $\left.T_{4}\right)$ alone for two months and combined triiodothyronine and thyroxine $\left(\mathrm{T}_{3} / \mathrm{T}_{4}\right)$ for two months in random rotation. The tablets were issued from the hospital pharmacy, but the doctor, technical staff, dispensing pharmacists, and patient were not aware of their identity.

Dosage.-When on L-thyroxine sodium the same dose $(200$ or $300 \mu \mathrm{g}$.) was prescribed for each patient as they had received before the trial. On the combination of hormones the tablets were identical in appearance and taste to the $T_{4}$ ablets and the same number were given daily (two or three) as were prescribed before the study and in the thyroxine part 
of the trial; each one contained L-triiodothyronine $20 \mu \mathrm{g}$. and L-thyroxine $80 \mu \mathrm{g}$. as the monosodium salts. For a month before the trial the patients had been asked to change from taking thyroxine as a single daily dose to a dose of one tablet spaced at 12-hourly intervals if taking two tablets each day or eight-hourly with three tablets each day, so that this regimen could be continued during the trial. Each bottle contained 200 tablets, and the patients were told that there were excess tablets and requested to return the bottle and remaining tablets on the next visit.

Procedure.-Throughout the trial the patients' appointments were on a different day from the routine clinic and they were seen exclusively by one doctor (R.N.S.) on each of the three attendances. At the first visit the details and purposes of the trial were fully explained again and a record card of personal and medical data, including all medications, was prepared. The prescription was issued and the patient askce to start taking these tablets at the next scheduled dose. Duriag the second visit eight weeks later a prescription for the secord reatment was issued, the first bottle and remaining tablets were retained by the staff, and a $20-\mathrm{ml}$. venous blood sar jie was taken (S.A.T.). On the third visit the patient cimpleted a questionnaire before the second blood sample was taken and the second bottle of tablets collected. The questionnaire asked whether the patients had observed any diffe ence during the two treatment periods and if one treatment was preferred or not. They were asked also to list any side effects and intercurrent illnesses during each twomonth period. On completion of the trial patients were given a routine clinic appointment and a prescription for thyroxine. The results of the trial were explained to them later.

Estimations.-The sera were divided into aliquots and stored at $-20^{\circ} \mathrm{C}$. The serum protein-bound iodine (P.B.I.) values were estimated (J.C.M.) with a modified Autoanalyzer method (Technicon) based on duplicate estimations with a standard thyroxine solution and two control sera (Versatol and Versatol A) in each batch. The Abbott Triosorb-131 kit (77977) was used for the ${ }^{131}$ I-labelled triiodothyronine resinsponge $\left(\mathrm{T}_{3}\right)$ uptake tests carried out in duplicate with a pooled sera control.

Analysis.-The laboratory and clinical data were transferred to record cards before the treatment sequence was decoded.

\section{Results}

Initially, 99 patients were included in the trial but four were withdrawn during it-two defaulted, one misunderstood the instructions, and one had a myocardial infarction while taking thyroxine-and eight were excluded from analysis because they failed to take $25 \%$ or more of the prescribed tablets; thus 87 patients were left (Table I). The age distribution in the three groups of patients differed $(P<0.001)$.

Accuracy of Medication.-Deficiencies in medication totalled $56 \%$ overall and some took excess (Table II). Only in the radioiodine group did any patients $(45 \%)$ take the exact number of tablets during the four months.

Adverse Effects.-Patients recorded unpleasant symptoms mare often on the $T_{3} / T_{4}$ tablets, and these symptoms probably accounted for the rejection of these tablets by 24 patients; five patients recorded two or more symptoms, thus accounting for the total recorded (Table III). Of the 24 patients, 14 were taking two tablets and 10 were taking three tablets daily. The incidence of intercurrent illnesses was the same on both treatments. The association between the occurrence of symptoms and choice of treatment was significant $\left(\chi^{2} ; \mathrm{P}<0.001\right)$. The sequence of treatment did not influence the incidence of adverse effects.

Patients' Preference.-Of 87 patients, 42 had no preference for either of the treatments, 16 preferred the combined $\left(T_{3} / T_{4}\right)$ tablets, and 29 preferred thyroxine $\left(T_{4}\right)$ alone
(Table IV). The sequence of therapy and dosage of tablets had no effect on the patients' choice.

Biochemical Tests.-The mean difference in duplicate serum P.B.I. estimations was $0.1 \mu \mathrm{g} . / 100 \mathrm{ml}$. (S.D. \pm 1.5 ) and for $T_{3}$ uptake estimations was $0.1 \%$ (S.D. \pm 0.6 ). The serum P.B.I. values were reduced on the $T_{3} / T_{4}$ tablets (mean reduction $1.8 \mu \mathrm{g} . / 100 \mathrm{ml}$.) in all groups irrespective of the dosage of tablets (Table V). The $T_{3}$-uptake values were not significantly altered and the mean values were in the upper normal range. The "free thyroxine indices" were reduced. An

TABLE I.-Distribution of Patients in the Two Dosage Groups and According to Sex and Age

\begin{tabular}{|c|c|c|c|c|c|c|}
\hline & & \multicolumn{2}{|c|}{ Daily Dose } & \multirow{2}{*}{ Total } & \multicolumn{2}{|c|}{ Sex } \\
\hline & & 2 Tablets & 3 Tablets & & Male & Female \\
\hline $\begin{array}{l}\text { No. } \\
\text { Age }\end{array}$ & $\because \quad \begin{array}{l}\because \text { Mean } \\
\text { Range }\end{array}$ & $\begin{array}{l}{ }_{45}^{11} S^{55} \\
46-76\end{array}$ & $\begin{array}{c}\text { ntaneous } G \\
10 \\
52 \\
44-69\end{array}$ & 21 & 3 & 18 \\
\hline $\begin{array}{l}\text { No. } \\
\text { Age }\end{array}$ & 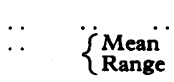 & $\begin{array}{c}99 \\
34-66\end{array}$ & $\begin{array}{l}79 \\
29-63\end{array}$ & 16 & 1 & 15 \\
\hline \multirow[t]{2}{*}{$\begin{array}{l}\text { No. } \\
\text { Age }\end{array}$} & $\ddot{\{} \begin{array}{l}\text { Mean } \\
\text { Range }\end{array}$ & $\begin{array}{l}36 \\
61 \\
40-71\end{array}$ & $\begin{array}{l}\text { ioiodine } G r \\
14 \\
56 \\
36-64\end{array}$ & 50 & 9 & 41 \\
\hline & Total & 56 & 31 & 87 & 13 & 74 \\
\hline
\end{tabular}

TABLE II.-Errors in Medication in the Four Months of the Trial

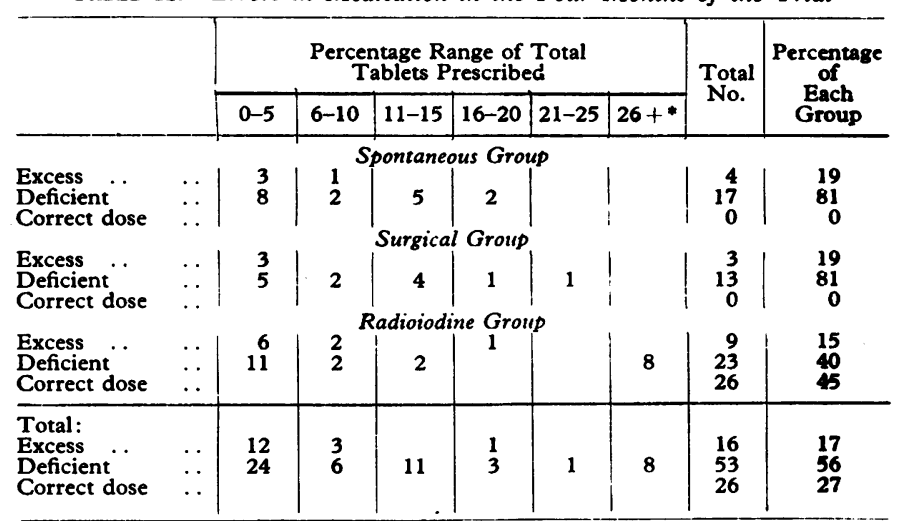

*Excluded from analysis in trial.

TABLE III.-Number of Patients Recording Side Effects and Intercurrent

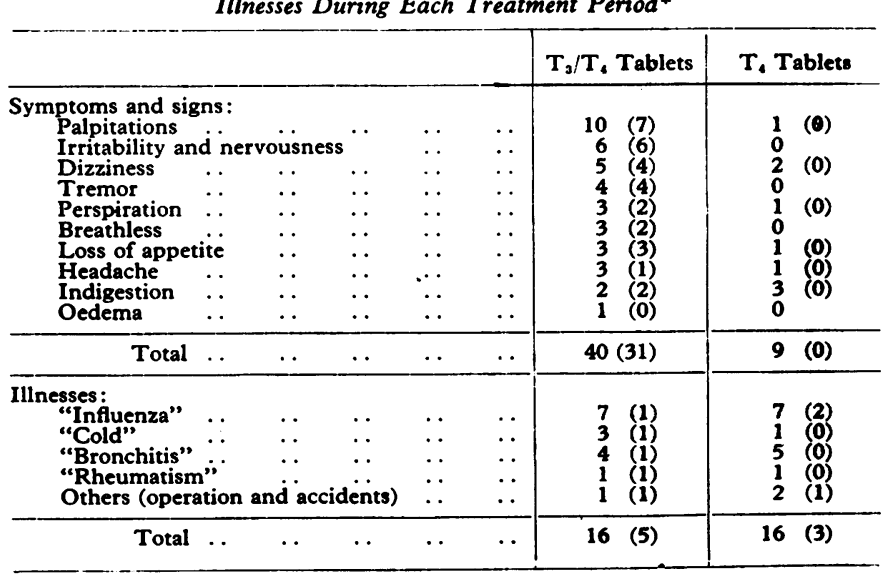

*Numbers in parentheses indicate the number of patients who rejected the tablets.

TABLE IV.-Number of Patients Indicating No Preference or Preference for One Treatment in the Three Groups

\begin{tabular}{|c|c|c|c|c|}
\hline & \multicolumn{4}{|c|}{ Patient's Preference of Treatment } \\
\hline & None & $T_{3} / T_{4}$ & $T_{0}$ & Total \\
\hline $\begin{array}{l}\text { Spontaneous } \\
\text { Surgical } \\
\text { Radioiodine }\end{array}$ & $\begin{array}{l}11 \\
4 \\
27\end{array}$ & $\begin{array}{l}2 \\
7 \\
7\end{array}$ & $\begin{array}{r}8 \\
5 \\
16\end{array}$ & $\begin{array}{l}21 \\
16 \\
50\end{array}$ \\
\hline Total & $42(48 \cdot 3 \%)$ & $16(18 \cdot 4 \%)$ & $29(33.3 \%)$ & 87 \\
\hline
\end{tabular}


TABLE V.-Mean Biochemical Values on Each Treatment and Dose in Three Groups of Patients

\begin{tabular}{|c|c|c|c|c|c|c|c|}
\hline & \multirow{3}{*}{ Treatment } & \multicolumn{2}{|c|}{ Spontaneous } & \multicolumn{2}{|c|}{ Surgical } & \multicolumn{2}{|c|}{ Radioiodine } \\
\hline & & \multicolumn{2}{|c|}{$\begin{array}{l}\text { No. of } \\
\text { Tablets }\end{array}$} & \multicolumn{2}{|c|}{$\begin{array}{l}\text { No. of } \\
\text { Tablets }\end{array}$} & \multicolumn{2}{|c|}{$\begin{array}{l}\text { No. of } \\
\text { Tablets }\end{array}$} \\
\hline & & 2 & 3 & 2 & 3 & 2 & 3 \\
\hline $\begin{array}{l}\text { Serum P.B.I. } \\
(\mu \mathrm{g} . / 100 \mathrm{ml} .)^{*} \ldots\end{array}$ & $\left\{\mathrm{T}_{3} \mathrm{~T}_{4}\right.$ & $\begin{array}{l}8 \cdot 1 \\
6 \cdot 4\end{array}$ & $\begin{array}{l}9.5 \\
7.8\end{array}$ & $\begin{array}{l}8 \cdot 7 \\
7 \cdot 3\end{array}$ & $\begin{array}{r}10 \cdot 4 \\
8 \cdot 0\end{array}$ & $\begin{array}{l}8 \cdot 8 \\
6 \cdot 9\end{array}$ & $\begin{array}{r}11 \cdot 2 \\
9 \cdot 5\end{array}$ \\
\hline$T_{3}$-uptake $\left(\begin{array}{l}0 \\
0\end{array}\right) \dagger$ & $\left\{\mathrm{T}_{3 /} \mathbf{T}_{4}\right.$ & $\begin{array}{l}31 \cdot 8 \\
31 \cdot 9\end{array}$ & $\begin{array}{l}33 \cdot 1 \\
34 \cdot 4\end{array}$ & $\begin{array}{l}32 \cdot 0 \\
31 \cdot 2\end{array}$ & $\begin{array}{l}33 \cdot 7 \\
34 \cdot 3\end{array}$ & $\begin{array}{l}31 \cdot 7 \\
32 \cdot 9\end{array}$ & $\begin{array}{l}34.9 \\
33.9\end{array}$ \\
\hline "Free thyroxine index". & $\left\{\mathrm{T}_{3}, \mathrm{~T}_{4}\right.$ & $\begin{array}{l}262 \cdot 3 \\
213 \cdot 3\end{array}$ & $\begin{array}{l}310 \cdot 0 \\
269 \cdot 1\end{array}$ & $\begin{array}{l}277 \cdot 4 \\
230 \cdot 1\end{array}$ & $\begin{array}{l}319 \cdot 0 \\
265 \cdot 3\end{array}$ & $\begin{array}{l}282 \cdot 4 \\
231 \cdot 1\end{array}$ & $\begin{array}{l}392 \cdot 1 \\
312 \cdot 6\end{array}$ \\
\hline
\end{tabular}

- Normal range 3.8-8.0 $\mathrm{\mu g} / 100 \mathrm{ml}$. †Normal range $30+5 \%$.

analysis of variance confirmed the significance of the changes in the serum P.B.I. $(P<0.001)$ and "free thyroxine indices" $(\mathrm{P}<0.001)$ in the radioiodine group, which contained most patients (Table V). The mean serum P.B.I. values of patients preferring the combined preparation were not significantly different from the mean values of patients preferring thyroxine alone or those of patients with no preference. Likewise, the $\mathrm{T}_{3}$ uptake values did not differ.

\section{Discussion}

Dried thyroid extracts of animal origin have a variable content of thyroxine and triiodothyronine and their biological potency is uncertain (Macgregor, 1961; Catz et al., 1962; Devlin and Stephenson, 1962; Wiberg et al., 1962; Pileggi et al., 1965; Devlin and Watanabe, 1966; Kologlu et al., 1966; Lemieux and Talmage, 1966). It has been recommended that dried thyroid extracts should be replaced by synthetic thyroxine or triiodothyronine because they have a reproducible metabolic effect (Macgregor, 1961). Both hormones are effective when given singly in the treatment of hypothyroidism, but thyroxine has been more widely used because it has been available for some years and has a longer biological half-life than triiodothyronine. Since the discovery of triiodothyronine, however, there has been hesitation in accepting that one hormone can be the equivalent of the two endogenous thyroid hormones (Lavietes and Epstein, 1964). This doubt has been reinforced by the relatively high serum P.B.I. values observed in patients on thyroxine therapy. Accordingly, several combined formulations of the two synthetic hormones have been introduced to find the optimum combination of triiodothyronine and thyroxine; a $1: 4$ ratio has been claimed to be the most effective (Selenkow and Wool, 1967; Sachs et al., 1968), but these patients had untreated hypothyroidism and medications were not strictly compared. More recently a 15:50 ratio of triiodothyronine to thyroxine has been advocated on the basis of an uncontrolled and limited study (Taylor et al., 1970).

All these studies (Selenkow and Wool, 1967; Sachs et al., 1968; Taylor et al., 1970) report serum P.B.I. values within the normal range in patients receiving the combined therapy. Increased well-being of the patients was expected because most of them had been hypothyroid before the studies started, but there was no strict comparison with thvroxine therapy. Subjective comments in the latest study (Taylor et al., 1970) of benefit from the combined treatment may be valid but equally may be due to other factors which cannot be excluded and which are inherent in uncontrolled therapeutic studies. The present study was designed to avoid these criticisms and to compare a 1:4 ratio of triiodothyron'ne and thyroxine with thyroxine alone in patients previously stabilized on thyroxine.

In this trial the patients were classified in three groups according to the cause of their hypothyroidism. Consequently, the age distribution differs between groups because treatment of thyrotoxicosis with radioiodine is confined to those over 40 years, whereas thyroid surgery is preferred for most younger patients; spontaneous hypothyroidism may occur in a wider age range (Table I). Analysis of the results in the trial have included independent calculations for each group and dosage because of the imbalance in size and age distribution of the three groups.

The reliability of patients in taking their tablets was similar to that found in other recent studies (Gatley, 1968; Porter, 1969). Eight patients were excluded from analysis owing to deficiencies of $25 \%$ or more in the medication actually taken. Other patients also took fewer tablets than prescribed and a few took more (Table II) but the decision to accept patients with deficiencies of less than $25 \%$ was arbitrary; fortunately, the error was similar in both treatment periods. Despite regular attendance at two-monthly intervals during the trial this level of discrepancy between the prescribed and actual dosage emphasizes that the error might be higher with long-term follow-up (Hedley et al., 1970).

Adverse symptoms have been reported with triiodothyronine alone (Frawley et al., 1956) and preparations containing it (Sachs et al., 1968), and most of them can be attributed to the total dose of the hormone. The total doses of combined triiodothyronine $(60 \mu \mathrm{g}$.) and thyroxine $(240 \mu \mathrm{g}$.) were higher in this trial for patients taking three tablets daily than in other studies. The incidence of reported symptoms was similar, however, in the two-tablet (14 patients) and three-tablet group (10 patients). Furthermore, these symptoms were not related to intercurrent illnesses, which occurred with equal frequency during therapy with the two preparations. Nevertheless, the two preparations in this trial differed in their metabolic potency because triiodothyronine has greater biological activity than thyroxine and, consequently, the doses were not equivalent in biological effectiveness. This discrepancy was unavoidable in designing the trial so that patients received the same number of tablets in each period.

About half the patients in this trial were unable to distinguish any difference between the combined tablets and thyroxine alone. Few patients $(18 \%)$ preferred the combination, and there was a high incidence of unpleasant symptoms repored by other patients during treatment with $T_{3} / T_{4}$ tablets. Many of these patients (24) stated a preference for thyroxine which was almost certainly influenced by the undesirable symptoms probably produced by the triiodothyronine component in the combined preparation. The patient's choice was not related to the seauence of treatment or laboratory tests of thyroid status and was similar in both dosage groups.

The reduction of serum P.B.I. confirms other reports with $\mathrm{T}_{3} / \mathrm{T}_{4}$ combinations (Wool and Selenkow, 1965; Selenkow and Wool, 1967; Sachs et al., 1968) and reflects the reduction in to al dose of thyroxine administered. The alteration in the $\mathrm{T}_{3}$-uptake values was variable (range $+9.2 \%$ to $-10.4 \%$ ) but not significant. Nevertheless, the "free thyroxine index" (Goolden et al., 1967) fell significantly on the combined preparation owing to alteration in the serum P.B.I. values. On the combined preparation and on thyroxine alone the mean $T_{3}$-uptake values were within the normal range $(30.0 \% \pm 5.0)$; a few values were high. Evidence of alteration in $T_{3}$-uptake values during thyroid replacement therapy is limited to studies of small numbers of patients. On thyroxine the value can be high (Levy et al., 1964), but other workers have found normal values on thvroxine (Mitchell et al., 1960; Alley et al., 1968: Goolden, 1969) and with combinations of the two thuroid hormones (Mitchell et al., 1960; Wool and Selenkow, 1965; Selenkow and Wool, 1967; Alley et al., 1968). In this larger series of patients the normal $T_{3}$-uptake values indicate that the thyroxine-binding globulin levels remained constant during each treatment.

Though this and other ratios of triiodothyronine and thyroxine, when given in adequate replacement doses, will produce normal serum P.B.I. values it is questionable whether either these values or those of the $T_{3}$-uptake tests have anv clinical importance in this situation (Harland and Orr, 1969). Certainly, clinical assessment is more helpful in 
adjusting the dosage of thyroid hormones, and the formulation of different ratios of the two hormones to achieve "normal" serum P.B.I. values is pointless if thyroxine alone relieves all the features of hypothyroidism. Thyroxine was well tolerated by patients in this trial, which accords with previous clinical experience, and it can be given conveniently as a single daily dose because it has a long biological half-life. There is no published evidence that patients treated with thyroxine alone suffer any ill effects due to the absence of triiodothyronine.

Fixed-ratio combinations of triiodothyronine and thyroxine cannot be expected to mimic precisely the continuous endogenous secretion of thyroid hormones because the rapid absorption and high biological activity of the triiodothyronine component may produce fluctuations in metabolic activity with untoward symptoms. Other studies have devoted most attention to the effects of combined preparations on laboratory tests, which have limited therapeutic importance in this situation (Harland and Orr, 1969), and have failed to conduct a valid clinical comparison. The shortcomings of combined therapy deduced from this study suggest that thyroxine has overall advantages for thyroid replacement therapy.

Glaxo Laboratories Ltd. supplied the combined tri-iodothyronine and thyroxin, the thyroxine (Eltroxin), and also the Triosorb 131 kits (Abbott Laboratories Ltd.). Mr. J. D. Cronin, chief pharmacist, and his staff at the Royal Infirmary, issued the coded tablets. We thank Dr. A. Jordan, Professor R. Kilpatrick, Professor D. S. Munro, and Dr. A. J. Smith in the two departments for their criticism of the manuscript and, finally, Professor G. M. Wilson for his advice in the planning of the trial.
REFERENCES

Alley, R. A., et al. (1968). Metabolism, 17, 97.

Catz, B., Ginsburg, E., and Salenger, S. (1962). New England fournal of

Medicine, 266, 136 .
Devlin, W. F., and Stephenson, N. R. (1962). Journal of Pharmacy and Pharmacology, 14, 597.

Devlin, W. F., and Watanabe, H. (1966). Journal of Pharmaceutical Sciences, $55,390$.

Frawley, T. F., McClintock, J. C., Beebe, R. T., and Marthy, G. L. (1956). Fournal of the American Medical Association, 160, 646.

Gatley, M. S. (1968). Journal of the Royal College of General Practitioners, $16,39$.

Goolden, A. W. G. (1969). Personal communication.

Goolden, A. W. G., Gartside, J. M., and Sanderson, C. (1967). Lancet, 1, 12.

Harland, W. A., and Orr, J. S. (1969). Scottish Medical fournal, 14, 375.

Hedley, A. J., Flemming, C. J., Chesters, M. I., Michie, W., and Crooks, J. (1970). British Medical fournal, 1, 519.

Kologlu, S., Schwartz, H. L., and Carter, A. C. (1966). Endocrinology, 78,

231.
Lavietes, P. H., and Epstein, F. H. (1964). Annals of Internal Medicine, $60,79$.

Lemieux, R., and Talmage, J. M. (1966). Journal of Pharmacy and Pharmacology, 18, 94.

Levy, R. P., Marshall, J. S., and McGuire, W. L. (1964). Metabolism, 13,

Macgregor, A. G. (1961). Lancet, 1, 329

Mitchell, M. L., Harden, A. B., and O'Rourke, M. E. (1960). Fournal of Clinical Endocrinology and Metabolism, 20, 1474.

Pileggi, V. J., Golub, O. J., and Lee, N. D. (1965). Fournal of Clinical Endocrinology and Metabolism, 25, 949.

Porter, A. M. W. (1969). British Medical fournal, 1, 218.

Sachs, B. A., Wolfman, L., and Murthy, G. (1968). Amcrican Journal of the Medical Sciences, 256, 232.

Selenkow, H. A., and Wool, M. S. (1967). Annals of Internal Medicine, 67, 90.

Taylor, S. (1961). Lancet, 1, 341.

Taylor, S., Kapur, M., and Adie, R. (1970). British Medical fournal, 2, 270.

Wiberg, G. S., Devlin, W. F., Stephenson, N. R., Carter, J. R., and Blayne, A. J. (1962). Journal of Pharmacy and Pharmacology, 14, 777.

Wool, M. S., and Selenkow, H. A. (1965). Clinical Pharmacology and Therapeutics, 6, 710.

\title{
Comparison of the Efficacy of Liquid and Freeze-dried Strains of B.C.G. Vaccine in Preventing Tuberculosis
}

\author{
V. H. SPRINGETT, ${ }^{*}$ M.D., F.R.C.P. ; IAN SUTHERLAND, $\dagger$ M.A.; D.PHIL.
}

\begin{abstract}
Cummary: Analysis of the tuberculosis notifications and the statistics of B.C.G. vaccinations among 13-year-old schoolchildren in Birmingham, England, between 1953 and 1969 shows that the Copenhagen strain of B.C.G. (liquid batches issued 1953-61) and the Glaxo Laboratories strain (freeze-dried batches issued 1962-68) were of similar high efficacy in the prevention of tuberculosis. The method of analysis could be used for the surveillance of the protective efficacy of B.C.G. vaccine in other population groups where it is used routinely but not universally.
\end{abstract}

\section{Introduction}

In an earlier paper one of us reported the results of B.C.G. vaccination of 13-year-old Birmingham schoolchildren during 1956-67 (Springett, 1969). The analysis of results was directed towards the age distribution of the tuberculosis notifications and to detecting any secular trend in the notifications in vaccinated and other groups. It is also possible to analyse the results in terms of periods of vaccination. The object of this paper is to report such a comparison for the periods before and after 16 December, 1961, when the change was made in

\footnotetext{
- Medical Director, Birmingham Chest Service. t Director, M.R.C. Statistical Research and Services Unit, London
W.C.1.
}

Birmingham from liquid B.C.G. vaccine (Copenhagen strain) to freeze-dried B.C.G. vaccine (Glaxo laboratories strain).

\section{Method}

For the purpose of this comparison the following additional data have been extracted from the records: (a) information for a further two years of follow-up (1968 and 1969) and for a further two cohorts of children (aged 13 years last birthday on 31 August in 1967 and in 1968); and (b) a separation of the published follow-up information for the two-year period 1962-3 into the calendar years 1962 and 1963-this permits the follow-up of the earlier cohorts (given liquid vaccine) to be terminated, for the purpose of this study, after about the same duration and over the same range of ages as is now available for the later cohorts (given freeze-dried vaccine).

The basic information has been assembled and the calculations have been performed, in exactly the same way as was done by Springett (1969). In particular the numbers of unvaccinated tuberculin-negative subjects, and the notifications of tuberculosis among them, were estimated from the figures for all non-participants in the vaccination scheme, $(a)$ by reducing the total number of non-participants by the proportion of particinants who were tuberculin-positive, and $(b)$ by reducing the total cases of tuberculosis among non-participants by the numbers expected (from the known experience of the 